\title{
Andrzej PODRAZA
}

Katolicki Uniwersytet Lubelski Jana Pawła II

podraza@kul.pl

\section{PROMOCJA DEMOKRACJI A BEZPIECZEŃSTWO EUROPEJSKIE: SKUTECZNOŚĆ I DYLEMATY POLITYKI WSCHODNIEJ UNII EUROPEJSKIEJ W XXI W.}

ABSTRACT Democracy promotion and European security: effectiveness and dilemmas of Eastern policy of the European Union in the 21 st century

The main aim of the article is a theoretical and empirical analysis of the impact of the European Union on the democratization process in the countries of Eastern Europe. In its foreign policy the European Union, regarded as a normative power, has a strategic interest in stabilizing neighbouring countries through the export of democratic values in order to ensure its own security. It is claimed, however, that the European Union's ability to influence the outside world is limited. The effectiveness of the EU's conditionality policy is mainly related to the perceived benefits by third countries - in case of Eastern European countries a membership offer as the main incentive is not yet taken into account. Of great importance there is also a lack of common EU position towards Russia, which regards a European export of democratic values to countries of the post-Soviet area as a challenge to its position on the international arena. A European-Russian rivalry on the post-Soviet area can be then described using realist theory of international relations. The article ends with recommendations for the European Union.

Słowa kluczowe: UE, potęga normatywna, promocja demokracji, realizm, Rosja Key words: EU, a normative power, democracy promotion, realism, Russia 


\section{WSTĘP}

Unia Europejska doświadcza obecnie szeregu istotnych kryzysów, które mogą wpłynąć na jej funkcjonowanie w przyszłości. Mają one zarówno charakter wewnętrzny, jak i dotyczą aktywności Unii na arenie międzynarodowej. Ich skutki mogą podważyć obecny model integracji i doprowadzić nawet do znaczącej transformacji UE w obecnym kształcie. Może bowiem dojść do przyjęcia jakiejś koncepcji zróżnicowanej integracji i wyodrębnienia twardego rdzenia, czyli grupy takich państw, które znacząco pogłębią integrację w kilku obszarach. Scenariusz taki, jakkolwiek nie do końca jeszcze realistyczny, wynika z faktu, że u podstaw obecnych kryzysów leżą poważne różnice zdań pomiędzy państwami członkowskimi co do radzenia sobie z wyzwaniami wewnętrznymi, jak i zewnętrznymi stojącymi przed Unią Europejską. Do najważniejszych można zaliczyć kryzys w strefie euro, stosunek do uchodźców i migrantów z Bliskiego Wschodu i Afryki oraz zróżnicowane podejście do Rosji w związku z aneksją Krymu i konfliktem we wschodniej Ukrainie. Wszystkie one są ilustracją głębokich podziałów nie tylko pomiędzy państwami członkowskimi, ale również w ramach poszczególnych państw.

W tym kontekście zasadne jest zadanie pytania o wartości, na których oparty jest projekt integracji w ramach Unii Europejskiej oraz o strategię tego podmiotu wobec świata zewnętrznego. Nie ulega wątpliwości, że obecne kryzysy dotyczą istoty rozwiązań demokratycznych w wymiarze wewnętrznym, jak i możliwości eksportu wartości demokratycznych do państw trzecich w celu ich stabilizacji. Kiedy w latach 50. XX w. powstawały Wspólnoty Europejskie, celem ojców założycieli było doprowadzenie do stworzenia pokojowej Europy, która z czasem w sposób funkcjonalny miała na fundamentach gospodarczych doprowadzić do przekształcenia się w strukturę federalną. Zakładano więc, że będzie ona mieć charakter demokratyczny. Kryzys w strefie euro udowodnił jednak, że w ramach Unii Europejskiej mamy nadal do czynienia z problemem deficytu demokracji, gdyż transnarodowa demokracja nie została wykształcona, a procesy decyzyjne można opisywać bardziej w kategoriach technokratycznych form elitystycznego zarządzania, czego przykładem może być narzucanie Grecji przyjęcia określonych pakietów oszczędnościowych przez instytucje ponadnarodowe, jak Komisja Europejska czy Europejski Bank Centralny ${ }^{1}$.

Problemy dużej fali uchodźców i migrantów z Bliskiego Wschodu i Afryki oraz przyjęcia jednolitej polityki wschodniej w związku z kryzysem ukraińskim są natomiast przejawem trudności z eksportem wartości demokratycznych do państw sąsiedzkich. Unia Europejska, postrzegana na ogół jako mocarstwo cywilne, czyli takie, które stosuje przede wszystkim instrumenty niemilitarne, nie potrafi wypracować takiej strategii, dzięki której bezpieczeństwo byłoby gwarantowane poprzez rozwój reżimów demokratycznych. Arabska wiosna, jak i agresja Rosji na Ukrainie ukazały niemoc Unii Europejskiej w reagowaniu na istotne wyzwania w najbliższym środowisku międzynaro-

R. Pitty, Disintegrating European Austerity in Greece and Germany, [w:] Democracy and Crisis. Democratising Governance in the Twenty-First Century, red. B. Isakhan, S. Slaughter, Basingstoke 2014, s. 125 . 
dowym. Polityka zagraniczna Unii, uwzględniając wcześniejszą aktywność w ramach ustanowionej w 1970 r. Europejskiej Współpracy Politycznej², cierpi bowiem na szereg istotnych chorób, które wynikają nie tylko ze znacznego zróżnicowania interesów pomiędzy państwami członkowskimi, ale również z problemów strukturalnych mających związek z trudnością określenia istoty Unii jako podmiotu na arenie międzynarodowej.

W niniejszym artykule poddane są analizie kontrowersje wokół polityki wschodniej Unii Europejskiej. Głównym celem jest teoretyczna i empiryczna analiza wpływu Unii na proces demokratyzacji w państwach Europy Wschodniej ${ }^{3}$. Przyjmuje się, że Unia Europejska w swojej polityce zagranicznej ma strategiczny interes w stabilizacji państw sąsiedzkich poprzez eksport wartości demokratycznych w celu zapewnienia własnego bezpieczeństwa. Twierdzi się jednak, że zdolność Unii do wpływania na świat zewnętrzny jest ograniczona, co wynika z kilku przyczyn. Po pierwsze, polityka warunkowości, uzależniająca stopień intensyfikacji relacji Unii z państwami trzecimi, nie może być w pełni skuteczna, gdyż w przypadku państw Europy Wschodniej oferta członkostwa jako głównej zachęty nie jest na razie brana pod uwagę. Efektywność tej polityki, będącej głównym elementem strategii przedczłonkowskiej wobec państw Europy Środkowej i Wschodniej, które przystąpily do Unii Europejskiej 1 maja 2004 r., jest bowiem związana z postrzeganymi korzyściami przez państwa trzecie.

Po drugie, zmiany demokratyczne w Europie Wschodniej z powodu wielu czynników, takich jak nierozwinięte społeczeństwo obywatelskie, słabość struktur administracyjnych czy kolizja z interesami innych graczy, takich jak Rosja w przypadku obszaru poradzieckiego, nie zawsze przyczyniają się do wzmocnienia bezpieczeństwa globalnego i regionalnego. Stawia to pod znakiem zapytania możliwości stworzenia obszaru demokratycznego zarządzania (democratic governance) na granicy Unii i Europy Wschodniej. Można wobec tego zastanawiać się, czy granica może być szansą na dalszą współpracę lub czy stanie się barierą pomiędzy zintegrowaną i stabilną Europą a nieprzewidywalnym i niespokojnym Wschodem. Jest to pytanie o otwartość projektu integracyjnego na nowe państwa członkowskie w związku z powszechnie odczuwanym zmęczeniem rozszerzaniem Unii Europejskiej.

\section{POCZĄTKI POLITYKI WSCHODNIEJ UNII EUROPEJSKIEJ (LATA 90. XX W.) - GŁÓWNE PROBLEMY}

Problemy z definiowaniem polityki wschodniej wynikają w dużej mierze z trudności funkcjonowania Unii Europejskiej jako aktora na arenie międzynarodowej.

2 Jakkolwiek w niniejszym artykule mowa jest o polityce zagranicznej Unii Europejskiej, która powstała 1 XI 1993 r. na mocy Traktatu o UE z Maastricht, to jest ona traktowana jako kontynuacja działań podejmowanych w ramach ustanowionej w 1970 r. Europejskiej Współpracy Politycznej, która była pierwszym mechanizmem koordynacji polityk zagranicznych państw członkowskich Wspólnoty Europejskiej.

3 Na potrzeby niniejszego artykułu termin „Europa Wschodnia” obejmuje państwa europejskie powstałe w wyniku rozpadu Związku Radzieckiego. 
Pomimo że Wspólnoty Europejskie powstały w latach 50. XX w., to dopiero od początku lat 70., dzięki stworzeniu Europejskiej Współpracy Politycznej, państwa członkowskie zainicjowały współpracę w zakresie polityki zagranicznej. Z czasem kooperację rozszerzono na polityczne i ekonomiczne aspekty bezpieczeństwa, a dopiero po ustanowieniu Wspólnej Polityki Zagranicznej i Bezpieczeństwa (WPZiB), w ramach powołanej w 1993 r. Unii Europejskiej, zaczęto inicjować dyskusję o polityce obronnej, co zaowocowało stworzeniem Europejskiej (obecnie Wspólnej) Polityki Bezpieczeństwa i Obrony (WPBiO). Nie oznacza to jednak, że Unię możemy traktować jako potęgę militarną, gdyż możliwości prowadzenia działań o charakterze wojskowym są mocno ograniczone w porównaniu $\mathrm{z}$ aktywnością państw narodowych czy sojuszy wojskowych, jak NATO.

Rozwojowi obszarów dyskusji i działania Unii Europejskiej towarzyszyły reformy traktatowe ${ }^{4}$, nie udało się jednak dzięki nim rozwiązać podstawowych problemów międzynarodowej aktywności Unii. Pierwszym istotnym testem dla powstającej na początku lat 90. WPZiB było opracowanie kompleksowej strategii wschodniej, w ramach której reagowano by nie tylko na proces transformacji gospodarczej i politycznej w państwach Europy Środkowej i Wschodniej, ale uwzględniono by również skutki potencjalnie niebezpiecznych wydarzeń, jak rozpad Związku Radzieckiego i Jugosławii 5 . Aktywność Unii Europejskiej potwierdziła ograniczony charakter działań tej organizacji. Sukcesem okazała się polityka prowadzona wobec tych państw Europy Środkowej i Wschodniej, które bardzo wyraźnie od przełomu lat 80. i 90. XX w. akcentowały swoje aspiracje europejskie.

Zdefiniowanie polityki dyferencjacji i warunkowości, zgodnie z którą różnicowano stopień intensyfikacji stosunków gospodarczych i politycznych z państwami wdrażającymi znaczące reformy polityczne i gospodarcze, stanowiło istotny przełom w rozwoju strategii wschodniej Unii Europejskiej. Takie podejście stanowiło reakcję na hasło „powrotu do Europy”, pod którym przeprowadzona była tzw. rewolucja w państwach Europy Środkowej i Wschodniej. Polityka dyferencjacji i warunkowości stała się od początku lat 90. głównym elementem strategii Unii wobec Europy Środkowej i Wschodniej. Jednak jej skuteczność w tamtym okresie związana była z ofertą przyszłej akcesji do UE dla tych państw stowarzyszonych, które wypełnią warunki członkostwa, o czym podjęto decyzję na posiedzeniu Rady Europejskiej w Kopenhadze w czerwcu 1993 r.

O wiele więcej trudności doświadczyła Unia Europejska w związku z wypracowaniem jednolitego stanowiska wobec rozpadu Jugosławii i Związku Radzieckiego. Jeśli brać pod uwagę zróżnicowanie interesów poszczególnych państw członkowskich, reakcje na te wydarzenia ukazywały problemy z osiągnieciem jednolitego podejścia przez Unię Europejską. Polityka zagraniczna Unii cierpi bowiem, jak podkreślają m.in. John Peterson i Marlene Gottwald, na szereg chronicznych problemów, jak brak jedności,

$\mathrm{Na}$ temat reform traktatowych zob.: A. Podraza, Unia Europejska w procesie reform traktatowych, Lublin 2007.

5 Szerzej na temat polityki wschodniej Unii Europejskiej na początku lat 90. XX w. zob.: tenże, Stosunki polityczne i gospodarcze Wspólnoty Europejskiej z państwami Europy Środkowej i Wschodniej, Lublin 1996. 
niespójność oraz słabe przywództwo, i może być podważana przez wszystkie rodzaje rywalizacji, tj. pomiędzy rządami państw członkowskich, między instytucjami UE, a także między nimi a ministerstwami spraw zagranicznych ${ }^{6}$. W przypadku Jugosławii i Związku Radzieckiego problemem było ewentualne uznanie nowych państw powstających w wyniku procesów dezintegracyjnych. Unia Europejska miała trudności z „mówieniem jednym głosem” z uwagi na zróżnicowane podejścia państw członkowskich. Pomimo że w ramach ówczesnej Wspólnoty Europejskiej udało się sfomułować w grudniu 1991 r. warunki dyplomatycznego uznania nowych państw w Europie Wschodniej i na terytorium Związku Radzieckiego, to jednak osiągnięcie zgody w odniesieniu do konkretnego przypadku nie było łatwe. Przykładowo państwa członkowskie były wręcz zmuszone do uznania w styczniu 1992 r. Chorwacji z uwagi na determinację Niemiec, które stwierdziły wcześniej, że uznają Chorwację nawet w sytuacji, gdyby państwo to nie spełniało wcześniej zdefiniowanych kryteriów?

Polityka Unii całkowicie zawiodła wobec rozwijającego się konfliktu zbrojnego w rozpadającej się Jugosławii. Wyraźnie było widać, że w sytuacji nacjonalizmu i czystek etnicznych stosowanie jedynie polityki dyferencjacji i warunkowości nie przyniesie żadnych efektów. Polityka „kija i marchewki”, czyli sankcji i preferencji, mogła być jedynie skuteczna, gdy państwa nią objęte nie stosowały siły jako środka rozwiązywania problemów wewnętrznych bądź międzynarodowych. Rozpad Jugosławii ukazał niemoc Unii Europejskiej, która jako potęga niemilitarna nie była w stanie poradzić sobie z rozwiązaniem konfliktów rozgrywających się tuż za jej granicami ${ }^{8}$. Dopiero przeprowadzenie operacji lotniczych przez NATO przeciwko Serbom, co było wyrazem zmiany stanowiska Stanów Zjednoczonych, doprowadziło do stopniowego wygaszenia konfliktów w Bośni i Hercegowinie oraz w Kosowie.

\section{POLITYKA WSCHODNIA I WOBEC ROSJI A CHARAKTER UNII EUROPEJSKIEJ JAKO PODMIOTU NA ARENIE MIĘDZYNARODOWEJ - IMPLIKACJE TEORETYCZNE}

Określenie podstawowych zrębów polityki wschodniej na początku lat 90. XX w. było istotnym elementem w rozwoju Unii Europejskiej jako aktora na arenie międzynarodowej, jakkolwiek potwierdzało szereg problemów z rozwijaniem aktywności w zakresie

J. Peterson, M. Gottwald, The EU as a Global Actor, [w:] The European Union. How Does It Work?, red. D. Kenealy, J. Peterson, R. Corbett, Oxford 2015, s. 209, The New European Union Series.

A. Podraza, Stosunki polityczne..., s. 275-277.

8 Pogląd o fiasku działań UE w odniesieniu do wojen w byłej Jugosławii w latach 90. XX w. jest wyrażany dosyć powszechnie. Dopiero po zakończeniu konfliktów Unia zaczęła odgrywać aktywniejszą rolę w stabilizacji m.in. Bośni i Hercegowiny oraz Kosowa. Ana Juncos, analizując politykę UE wobec Bośni i Hercegowiny, określa Unię w latach 1991-1995 mianem nieefektywnej potęgi cywilnej, w latach 1996-1999 potęgi cywilnej (gospodarczej) bez strategii, a dopiero w odniesieniu do lat 1999-2005 zastanawia się, czy można rozpatrywać Unię jako regionalną potęgę normatywną, A. Juncos, The EU's Post-Conflict Intervention in Bosnia and Herzegovina: (Re)Integrating the Balkans and/or (Re)Inventing the EU?, „Southeast European Politics” 2005, Vol. 6, nr 2. 
Europejskiej Współpracy Politycznej, a od 1993 r. Wspólnej Polityki Zagranicznej i Bezpieczeństwa. Zarówno wówczas, jak i współcześnie Unia może być traktowana przede wszystkim jako potęga cywilna, której celem jest promowanie stabilności poprzez rozwój współpracy gospodarczej i handlowej, promocję demokracji, dobrych rządów i rządów prawa, lub też jako potęga normatywna, która dąży do stworzenia bardziej pokojowego świata przez rozpowszechnianie takich norm, jak demokracja, rządy prawa i prawa człowieka stanowiące podstawę normatywną UE. Jest więc ona ujmowana jako potęga niemilitarna, co ma wpływ na stawiane cele i używane instrumenty.

Dążeniem Unii jest stabilizacja państw sąsiedzkich poprzez używanie głównie instrumentów gospodarczych w ramach polityki warunkowości jako głównej strategii wobec sąsiadów. $Z$ uwagi na to, że stabilizacja wewnętrzna jest osiągana poprzez eksport tzw. modelu zachodniego, czyli gospodarki rynkowej i demokracji liberalnej, promocja demokracji jest jedną z podstawowych elementów strategii, co zgodne jest z liberalną teorią stosunków międzynarodowych. Oczywiście w tym kontekście można postawić pytanie, czy można interpretować politykę sąsiedztwa UE także przy użyciu innych podejść teoretycznych, tj. głównie realizmu (tworzenie europejskiej strefy wpływów, co w przypadku Ukrainy i innych państw Europy Wschodniej prowadzi do kolizji z Rosją) lub też konstruktywizmu społecznego z uwzględnieniem koncepcji wspólnoty bezpieczeństwa Karla Deutscha (eksport wartości demokratycznych w celu tworzenia obszaru demokratycznego zarządzania - democratic governance). Pytania te są niezwykle istotne, gdyż interpretacja strategii Unii wobec państw sąsiedzkich może pomóc w określeniu adekwatności poszczególnych teorii do analizy istoty UE jako podmiotu stosunków międzynarodowych.

Jakkolwiek Unia Europejska może być różnorako ujmowana jako aktor na arenie międzynarodowej, to przeważa pogląd, że nie może być ona traktowana jako tradycyjna potęga. Choć Unia używa różnorakich instrumentów o charakterze gospodarczym i politycznym, także w obszarze bezpieczeństwa i obrony, to jednak nie jest podmiotem uniwersalnym, który posiada samoistną zdolność prowadzenia wojny. Działania Unii w zakresie Wspólnej Polityki Bezpieczeństwa i Obrony ograniczają się jedynie do możliwości realizacji tzw. operacji petersberskich, czyli misji o różnorakim charakterze obejmujących operacje pokojowe, zarządzania sytuacjami kryzysowymi lub zadania humanitarne i ratunkowe?

Unia nie jest więc tradycyjną potęgą, gdyż jej działania w zakresie polityki zagranicznej nie tylko nie mają kompleksowego charakteru, ale co więcej, jej poczynania zewnętrzne pozostają w cieniu aktywności międzynarodowej państw członkowskich. Jest to widoczne przede wszystkim w odniesieniu do kwestii, które są istotne z punktu widzenia interesów poszczególnych państw. W takich sytuacjach bardzo często biorą one górę nad interesem unijnym. Może to prowadzić do przyjmowania wspólnych sta-

Misje petersberskie są wymienione w art. 43 ust. 1 Traktatu o Unii Europejskiej: Misje, o których mowa $w$ artykule 42 ustęp 1, przy prowadzeniu których Unia może użyć środków cywilnych i wojskowych, obejmują wspólne dziatania rozbrojeniowe, misje humanitarne i ratunkowe, misje wojskowego doradztwa $i$ wsparcia, misje zapobiegania konfliktom $i$ utrzymywania pokoju, misje zbrojne stuzace zarzadzaniu kryzysowemu, w tym misje przywracania pokoju i operacje stabilizacji sytuacji po zakończeniu konfliktów. 
nowisk, które kształtują się na poziomie najniższego wspólnego mianownika, lub też podejmowania przez niektóre państwa działań stojących w sprzeczności z podejściem Unii jako instytucji.

Tego rodzaju sytuacja wyraźnie zachodzi w odniesieniu do Rosji. Z jednej strony Unia Europejska wprowadziła ograniczone sankcje wobec tego państwa w reakcji na agresję na Ukrainie. Z drugiej jednak strony niektóre państwa członkowskie utrzymują nawet bliskie kontakty z Rosją, rozwijając relacje gospodarcze i polityczne. Co więcej, kryzys ukraiński ukazuje słabości w kreowaniu Unii Europejskiej jako ważnego podmiotu na arenie międzynarodowej. Najlepszym tego przykładem mogą być rozmowy w sprawie rozwiązania konfliktu ukraińskiego, które toczą się od 2014 r. w ramach tzw. formatu normandzkiego, tzn. z udziałem Niemiec, Francji, Rosji i Ukrainy ${ }^{10}$. Brak przedstawiciela Unii Europejskiej podczas tych negocjacji jest świadectwem instrumentalnego traktowania mechanizmów WPZiB przez największe państwa członkowskie. Ukazuje także słabość polityki wschodniej UE, gdyż w jej rozwoju większe znaczenie mają interesy najsilniejszych graczy niż Unii jako wspólnoty różnych interesów i państw, które dążą do wypracowania spójnego i ambitnego stanowiska.

Zróżnicowanie poglądów na temat Rosji widoczne jest chociażby wśród państw członkowskich UE z Europy Środkowej i Wschodniej, co w dużej mierze jest warunkowane względami geograficznymi i historycznymi. Polska, Estonia i Litwa w sposób jednoznaczny potępiły udział Rosji w konflikcie ukraińskim, a w szczególności aneksję Krymu i zaangażowanie militarne Moskwy w Donbasie ${ }^{11}$. Prezydent Estonii Toomas Hendrik Ilves oskarżył nawet Rosję o zainicjowanie bitwy pomiędzy Europą a nie-Europą, inaczej konfliktu wartości. Po przeciwnej stronie znajdują się państwa, które cechuje wstrzemięźliwość (Bułgaria), zdystansowanie (Rumunia), pragmatyzm (Słowacja) lub wyraźna prorosyjskość (Czechy i Węgry). Podziały są również widoczne pomiędzy państwami członkowskimi starej Unii Europejskiej. Brak jednoznacznego stanowiska wobec tak istotnego gracza, jakim jest Rosja, aspirująca do miana potęgi globalnej, jest istotną przeszkodą w kreowaniu Unii jako aktora na arenie międzynarodowej.

Pomimo że Unia Europejska nie jest na ogół ujmowana jako tradycyjna potęga, to nie brak oczywiście opinii, że następuje transformacja Unii polegająca na odejściu od rozwijania projektu pokojowego bazującego na cywilnej agendzie w kierunku aktora współzawodniczącego geopolitycznie, którego racja stanu koliduje z jej normatywnymi zobowiązaniami ${ }^{12}$. Zgodnie z takim podejściem Unia Europejska albo przyłącza nowe terytoria, co oczywiście ma miejsce w ramach procesów akcesyjnych, albo dąży do stworzenia strefy wpływów poprzez pogłębianie relacji gospodarczych i politycznych z państwami sąsiedzkimi. W takich kategoriach można by chociażby interpretować

10 Nazwa „format normandzki” ma związek ze spotkaniem przywódców czterech państw, które po raz pierwszy odbyło się 6 VI 2014 r. przy okazji obchodów 70. rocznicy lądowania wojsk alianckich na plażach Normandii w czasie II wojny światowej.

11 J. Forbrig, Introduction: A Region Disunited?, [w:] A Region Disunited? Central European Responses to the Russia-Ukraine Crisis, red. tenże, Washington 2015, s. 3, Europe Policy Paper, 1/2015.

12 R. Sakwa, The Death of Europe? Continental Fates after Ukraine, „International Affairs” 2015, Vol. 91 , nr 3, s. 553-554, [online] http://dx.doi.org/10.1111/1468-2346.12281. 
rozwój stosunków z Ukrainą, która pomimo braku obietnicy przyszłego członkostwa podpisała w 2014 r. umowę stowarzyszeniową z UE.

Z punktu widzenia teorii realistycznej można dojść do oczywistego wniosku, że taka polityka UE może być ujmowana przez Moskwę jako potencjalnie agresywny ruch mający na celu pomniejszenie roli i znaczenia Rosji na arenie międzynarodowej. Stąd dążenie Rosji do zajęcia z jej punktu widzenia należnego miejsca w systemie międzynarodowym, co może prowadzić do konfliktu z Unią Europejską i państwami członkowskimi, ale przede wszystkim z NATO i Stanami Zjednoczonymi. Poszerzanie składu członkowskiego zwłaszcza Sojuszu Atlantyckiego, ale również Unii Europejskiej o nowe demokracje z Europy Środkowej i Wschodniej doprowadziło do stworzenia nowego systemu bezpieczeństwa europejskiego, ale jednocześnie do pojawienia się na początku XXI w. państw wykluczonych, takich jak Rosja, ale również Ukraina ${ }^{13}$. Wynika to z trudności ze znalezieniem formuły współpracy pomiędzy poszerzonymi instytucjami Zachodu a w głównej mierze Rosją, która w odróżnieniu od Ukrainy nigdy nie aspirowała do członkostwa w NATO i UE. Ambicje mocarstwowe przy jednoczesnym poczuciu zmarginalizowania ograniczyły możliwości wpływania na politykę wewnętrzną i zagraniczną Rosji i tak niezbyt wpływowych liberalnych zwolenników westernizacji na rzecz pragmatycznych bądź fundamentalistycznych nacjonalistów. Ci ostatni traktowali poszerzenie NATO jako „strategiczny błąd” i rozważali możliwość ostrej reakcji poprzez znaczne zwiększenie wydatków militarnych i doprowadzenie do nowego wyścigu zbrojeń oraz postulowali rozważenie na nowo roli broni nuklearnej ${ }^{14}$.

Szczytowym punktem zaostrzenia stanowiska Rosji była aneksja Krymu na początku 2014 r. i militarne zaangażowanie wojsk rosyjskich we wschodniej Ukrainie, co było rezultatem jasnej deklaracji Kijowa o europejskich aspiracjach. Poszerzanie wpływów przez Unię Europejską i NATO na obszarze poradzieckim wzmacnia poczucie, że Rosja jest traktowana przez Zachód jako pokonana potęga, której godność i interesy nie są brane pod uwagę ${ }^{15}$. Można wręcz mówić o pojawieniu się „syndromu weimarskiego" związanego z asymetrycznym zakończeniem zimnej wojny. Jak postulują niektórzy, aby przełamać poczucie wykluczenia Rosji, należałoby zaoferować jej członkostwo w NATO, co jak się twierdzi, pozwoliłoby także takim państwom, jak Gruzja i Ukraina, na akcesję do Sojuszu Atlantyckiego bez antagonizowania Moskwy ${ }^{16}$.

Pomimo werbalnej atrakcyjności propozycja ta jest mało realna. Co więcej, można nawet stwierdzić, że ewentualne przystąpienie Rosji do NATO byłoby szkodliwe dla spójności i funkcjonowania Sojuszu Atlantyckiego, który szybko uległby marginalizacji i przekształciłby się w kolejną Organizację Bezpieczeństwa i Współpracy w Europie (OBWE). Nie można także zgodzić się opinią, że stosunek Rosji do rozszerzania

13 M. Light, S. White, J. Löwenhardt, A Wider Europe: The View from Moscow and Kyiv, „International Affairs" 2000, Vol. 76, nr 1, s. 77, [online] http://dx.doi.org/10.1111/1468-2346.00121.

14 Tamże, s. 79-81.

15 R. Sakwa, The Death of Europe?..., s. 556.

16 Ch.A. Kupchan, NATO's Final Frontier: Why Russia Should Join the Atlantic Alliance, „Foreign Affairs" 2010, Vol. 89, nr 3. 
NATO ulegnie zmianie z uwagi na ewentualne przekształcenie Sojuszu Atlantyckiego z zimnowojennego sojuszu wojskowego na rzecz głównie partnerstwa politycznego ${ }^{17}$. Bez względu na transformację NATO Rosja traktuje bowiem Sojusz jako zagrożenie własnego bezpieczeństwa, w tym przede wszystkim wypowiada się niezwykle mocno przeciwko dalszej ekspansji terytorialnej tej organizacji ${ }^{18}$.

Zasadne w tym kontekście jest postawienie pytania, czy przyczyn agresywnych działań Moskwy należy doszukiwać się w polityce Zachodu, w tym Unii Europejskiej, czy też jest to wynik bardzo ograniczonej transformacji Rosji, która może być opisywana jako państwo nie w pełni demokratyczne. Innymi słowy, czy działania Unii Europejskiej i NATO, realizujące politykę poszerzenia, są na tyle istotnym wyzwaniem dla Rosji, że staje się ona państwem ekspansywnym, uważającym, że obszar poradziecki jest jej naturalną strefą wpływów? Czy promocja demokracji wobec Rosji jest polityką, która nie przyniesie rezultatu z uwagi na brak jasno sprecyzowanych celów strategii Zachodu wobec Rosji? Czy w działaniach Rosji mocarstwowość ma większe znaczenie niż stworzenie podstaw porządku demokratycznego? Są to bardzo istotne pytania z punktu widzenia praktyki politycznej, ale również teorii polityki międzynarodowej.

Neoimperializm Władimira Putina, rozumiany przede wszystkim jako odmowa uznania pełnej suwerenności państw powstałych w wyniku rozpadu Związku Radzieckiego $^{19}$, co może skutkować działaniami Kremla w zakresie zmiany granic międzynarodowych, podważaniem legitymizacji rządów i terytorialnej integralności państw sąsiadujących z Rosją ${ }^{20}$, ma źródła przede wszystkim wewnętrzne. Rosja przez wieki prowadziła politykę kolonizacji państw sąsiedzkich, wobec czego nostalgia Putina za utraconym imperium i dążenie do jego przywrócenia nie powinny dziwić21. Konflikty w Czeczenii i Gruzji oraz wojna hybrydowa na Ukrainie są działaniami Rosji, które wynikają z konstatacji Putina, że rozpad Związku Radzieckiego był największą katastrofą geopolityczną XX w. ${ }^{22}$ Jednym z elementów aktywności Moskwy w tym zakresie jest realizacja wielkiej strategii zniszczenia Partnerstwa Wschodniego Unii Europejskiej i zastąpienia go przez własną politykę sąsiedztwa ${ }^{23}$.Zrealizowanie tego celu byłoby

17 Z. Barany, NATO's Peaceful Advance, „Journal of Democracy” 2004, Vol. 15, nr 1, s. 73, [online] http://dx.doi.org/10.1353/jod.2004.0002.

18 Putin Names Nato among Threats in New Russian Security Strategy, „Financial Times” 2016, 2 I, [online] http://www.ft.com/intl/cms/s/0/6e8e787e-b15f-11e5-b147-e5e5bba42e51.html\#axzz42cyIV x9l, 3 I 2016.

19 Taki sposób rozumienia polityki neoimperialnej jest m.in. przyjęty w: Russia’s Foreign Policy. Ideas, Domestic Politics and External Relations, red. D. Cadier, M. Light, Basingstoke 2015, Palgrave Studies in International Relations.

20 J. Bugajski, Russia’s Transformation, „The Journal of International Security Affairs” 2014, nr 27, [online] http://www.securityaffairs.org/issues/number-27/russias-transformation, 8 III 2016.

21 Szerzej na ten temat zob.: M.H. van Herpen, Putin's Wars. The Rise of Russia's New Imperialism, Lanham 2014.

22 Putin Deplores Collapse of USSR, BBC News, 25 IV 2005, [online] http://news.bbc.co.uk/2/ hi/4480745.stm, 11 VIII 2015.

23 M. Emerson, H. Kostanyan, Putin's Grand Design to Destroy the EU's Eastern Partnership and Replace It with a Disastrous Neighbourhood Policy of His Own, Brussels 2012, CEPS Commentary. 
katastrofalne dla polityki wschodniej Unii Europejskiej, ale również zatrułoby relacje Unii z Rosją. Przede wszystkim miałoby negatywny wpływ na takie państwa, jak Armenia, Mołdawia czy Ukraina, gdyż byłyby one odcięte od możliwości pełniejszego włączenia się w konkurencyjną gospodarkę globalną. Co więcej, państwa te byłyby poddane geopolitycznemu przymusowi ze strony Rosji, która odgrywa rolę hegemona w ramach powołanych przez siebie instytucji współpracy na obszarze poradzieckim. Przykładem może być Euroazjatycka Unia Gospodarcza (EUG) ${ }^{24}$, która powstała w 2015 r. i która po Euroazjatyckiej Unii Celnej i Wspólnej Przestrzeni Gospodarczej jest kolejną inicjatywą uzależnienia państw obszaru poradzieckiego. EUG nie jest skutecznym narzędziem integracji gospodarczej, ale jest traktowana przez Rosję jako instrument realizacji politycznych ambicji Władimira Putina. W odróżnieniu od Unii Europejskiej, która w swojej polityce sąsiedztwa stosuje przede wszystkim marchewkę, czyli zachęty do wewnętrznej modernizacji, Rosja w ramach EUG stosuje politykę kija, czyli wymuszania politycznej uległości wobec Kremla ${ }^{25}$.

Pomimo że Unii Europejskiej nie można nadal ujmować jako tradycyjnej potęgi, to Rosja traktuje Partnerstwo Wschodnie, którego celem jest zbliżenie państw Europy Wschodniej do zinstytucjonalizowanej Europy, jako wyzwanie zmierzające do pomniejszenia wpływów Moskwy na obszarze poradzieckim. Negatywny stosunek Rosji jest więc podyktowany obawą przed rozszerzeniem strefy demokracji, co w dalszej perspektywie może skutkować zachwianiem podstawami reżimu Putina lub jego następców. Rozprzestrzenianie się wartości, na których oparty jest projekt europejski, mogłoby bowiem ostatecznie doprowadzić do eksportu kolorowej rewolucji do Rosji. Po raz kolejny można dojść do przekonania, że działania Rosji są nie tyle podyktowane potrzebą realizacji strategii zagranicznej, ile wynikają przede wszystkim z pobudek wewnętrznych. Politykę Moskwy, której początków można się doszukiwać w połowie pierwszej dekady XXI w., można nazwać nowym powstrzymywaniem ${ }^{26}$. Celem Rosji jest przeciwdziałanie sukcesowi reform w takich państwach, jak Gruzja, Ukraina czy Kirgistan, które doświadczyły kolorowych rewolucji. Po odsunięciu Wiktora Janukowycza od władzy Moskwa dąży więc do ciągłego destabilizowania sytuacji na Ukrainie. Nie jest to podyktowane jedynie neoimperializmem Putina, bo w taki sposób można tłumaczyć aneksję Krymu i wspieranie rebeliantów we wschodniej Ukrainie. Rosja chce przeciwdziałać sukcesowi procesu demokratyzacji Ukrainy, bo zagrażałoby to skorumpowanemu systemowi rozwijanemu przez Kreml.

Analizując Unię Europejską jako aktora międzynarodowego, rywalizację z Rosją na obszarach wspólnego sąsiedztwa można teoretycznie wyjaśnić dwojako. Z jednej strony można posłużyć się realizmem, który jest najbardziej adekwatny do zrozumienia kon-

24 Państwami członkowskimi Euroazjatyckiej Unii Gospodarczej są: Armenia, Białoruś, Kazachstan, Kirgistan i Rosja.

25 A. Jarosiewicz, E. Fischer, Eurazjatycka Unia Gospodarcza - więcej polityki, mniej gospodarki, Warszawa 2015, Komentarze OSW, nr 157, [online], http://www.osw.waw.pl/pl/publikacje/komentarze-osw/2015-01-20/eurazjatycka-unia-gospodarcza-wiecej-polityki-mniej-gospodarki, 15 VIII 2015.

26 Ch. Walker, The New Containment. Undermining Democracy, „World Affairs” 2015, Vol. 178, nr 1, s. $43-47$. 
fliktów, jakkolwiek rzadko jest wykorzystywany do uchwycenia istoty integracji w ramach Unii Europejskiej. Z drugiej strony można przyjąć podejście normatywne, które byłoby zgodne zarówno z liberalizmem, jak i konstruktywizmem społecznym.

Zgodnie z propozycją neorealistyczną (realizmu strukturalnego) Andrew Hyde-Price’e państwa członkowskie pozwalają Unii Europejskiej na podejmowanie działań w imię wspólnych problemów etycznych, ale tylko wtedy, kiedy nie jest to sprzeczne $\mathrm{z}$ ich podstawowymi interesami narodowymi ${ }^{27}$. W związku z tym ograniczenia koncepcji Europy normatywnej widoczne są chociażby w sytuacji rozwoju relacji gospodarczych z Rosją lub sprzedaży broni do Chin. Unia, oddziałując na środowisko międzynarodowe, stosuje nie tylko instrumenty z zakresu miękkiej potęgi, takie jak perswazja dyplomatyczna, negocjacje czy kompromis, ale również twardej siły w formie polityki warunkowości, narzucając własny model polityczny i gospodarczy państwom postkomunistycznym ${ }^{28}$. Wobec państw sąsiedzkich Unia działa jak kolektywny hegemon, stosując siłę w różnych formach: partnerstwo polityczne lub ostracyzm, gospodarcze marchewki lub kije, obietnica członkostwa lub zagrożenie wykluczeniem. Konsekwencją takiego sposobu działania jest rosnący konflikt z Rosją o model bezpieczeństwa europejkkiego i miejsce w nim państw wspólnego sąsiedztwa.

Jeżeli Unia Europejska jest traktowana przede wszystkim jako potęga cywilna, to rywalizacja z Rosją na terytorium tzw. wspólnego sąsiedztwa przybiera charakter normatywny ${ }^{29}$. Rosja współzawodniczy więc z Unią Europejską, która przez długi czas posiadała monopol jako aktor normatywny. W celu wzmocnienia własnej pozycji na obszarze poradzieckim Rosja nie stosuje jedynie tradycyjnych instrumentów, takich jak zależność energetyczna, siła militarna czy też z zakresu soft power, ale dąży również do tworzenia opartego na regułach reżimu instytucjonalnego.

Normatywna rywalizacja, która jest przede wszystkim widoczna na Ukrainie i w Mołdawii, jest z punktu widzenia Rosji opisywana jako konflikt w kategoriach realistycznych. Moskwa nie uznaje bowiem, że czysto idealistyczne (liberalne) podejście przystaje do współczesnych stosunków międzynarodowych ${ }^{30}$. Uważa, że Unia Europejska podejmuje całkowicie racjonalne działania, maskując rzeczywiste intencje za takimi pojęciami, jak prawa człowieka, demokracja czy rządy prawa. Co więcej, zgodnie z takim sposobem myślenia Unia wkracza w strefę wpływów Rosji, nalegając na państwa obszaru poradzieckiego, aby dostosowywały prawo krajowe do acquis communautaire UE.

Podejście Rosji, mieszczące się w ramach realizmu, może być zaskakujące, gdyż stoi całkowicie w sprzeczności z ujmowaniem Unii Europejskiej jako aktora niemilitarnego, który działa zgodnie z najbardziej znanym postulatem teorii liberalnej „pokoju przez demokrację". Bazując na poglądach Immanuela Kanta i innych osiemnastowiecznych

27 A. Hyde-Price, „Normative” Power Europe: A Realist Critique, „Journal of European Public Policy” 2006, Vol. 13, nr 2, s. 223, [online] http://dx.doi.org/10.1080/13501760500451634.

28 Tamże, s. 227.

29 R. Dragneva, K. Wolczuk, Russia, the Eurasian Customs Union and the EU: Cooperation, Stagnation or Rivalry?, 2012, s. 9, Chatham House Briefing Paper, REP BP 2012/01.

30 T. Romanova, Normative Power Europe: A Russian View, [w:] Normative Power Europe in a Changing World. A Discussion, red. A. Gerrits, The Hague 2009, s. 56-57, Clingendael European Paper. 
myślicielach oświeceniowych, twierdzi się, że państwa demokratyczne nie przejawiają na ogół agresji w polityce zagranicznej i konflikt pomiędzy nimi jest mało prawdopodobny. Postulat „pokoju przez demokrację" jest wobec tego jednym z najważniejszych elementów strategii Unii Europejskiej wobec państw sąsiedzkich.

Punkt wyjścia do ujmowania Unii Europejskiej jako potęgi niemilitarnej stanowiły publikacje z początku lat 70. XX w. François Duchêne'a, swego czasu doradcy Jeana Monneta i jego późniejszego biografa. Charakteryzował on Wspólnotę Europejską jako potęgę cywilną, która posiada zdolność do eksportu własnego modelu zapewnienia stabilności i bezpieczeństwa za pomocą środków gospodarczych i politycznych, a nie militarnych ${ }^{31}$. Jakkolwiek koncepcja Duchêne’a nigdy nie była w pełni rozwinięta, taki sposób ujmowania UE jako podmiotu na arenie międzynarodowej zyskał prominentne miejsce zarówno w dyskursie politycznym, jak i teoretycznym ${ }^{32}$. Koncepcja potęgi cywilnej była definiowana przez innych badaczy, którzy stosowali ją w odniesieniu do państw. W 1990 r. Hanns W. Maull określił Niemcy i Japonię mianem globalnych potęg cywilnych ${ }^{33}$. Potęga cywilna cechuje się akceptacją konieczności współpracy z innymi podmiotami. Aby osiągnąć cele w polityce międzynarodowej, stosuje głównie instrumenty gospodarcze, a nie militarne oraz przejawia gotowość do rozwoju struktur ponadnarodowych, aby rozwiązywać kluczowe zagadnienia międzynarodowego zarządzania.

Na koncepcji Duchêne’a bazują późniejsze, jakkolwiek zróżnicowane koncepcje Unii Europejskiej jako potęgi cywilnej (Telò, 2007 r.), postmodernistycznej (Cooper, 2003 r.), etycznej (Aggestam, 2008 r.), strukturyzacyjnej (Keukeleire i MacNaughtan, 2008 r.), transformatywnej (Leonard, 2005 r.), miękkiej (Nye, 2002 r., 2004 r. i 2005 r.) oraz normatywnej (Manners, 2002 r.) $)^{34}$.

W ocenie wpływu Unii Europejskiej na państwa Europy Wschodniej szczególnie użyteczna i popularna jest koncepcja potęgi normatywnej, która początkowo, od 2000 r. była rozwijana przez Iana Mannersa. Oprócz ukazania istoty Unii jako aktora na arenie międzynarodowej oferuje ona trójdzielne ramy analityczne, dzięki którym można lepiej zrozumieć siłę normatywnego oddziaływania. Ramy te obejmują analizę zasad, które są promowane przez Unię, działań, które są podejmowane w celu promocji, oraz wpływ promocji $i^{35}$. Unia Europejska jest ujmowana jako wspólnota wartości

31 H. Sjursen, What Kind of Power?, [w:] Civilian or Military Power? European Foreign Policy in Perspective, red. taż, London-New York 2007, s. 1, Journal of European Social Policy.

32 J. Orbie, Civilian Power Europe. Review of the Original and Current Debates, „Cooperation and Conflict" 2006, Vol. 41, nr 1, s. 123, [online] http://dx.doi.org/10.1177/0010836706063503.

33 H.W. Maull, Germany and Japan: The New Civilian Powers, „Foreign Affairs” 1990, Vol. 69, nr 5, s. $92-93$.

34 A. Gerrits, Normative Power Europe: Introductory Observations on a Controversial Notion, [w:] Normative Power Europe in a Changing World..., s. 2.

35 I. Manners, The European Union's Normative Power in Global Politics, [w:] Key Controversies in European Integration, red. H. Zimmermann, A. Dür, Basingstoke 2012, s. 196-198, European Union Series; tenże, The Normative Ethics of the European Union, „International Affairs” 2008, Vol. 84, nr 1, [online] http://dx.doi.org/10.1111/j.1468-2346.2008.00688.x. 
konstytuujących ją jako podmiot, którego ustrój ma wpływ na ich promocję, czyli na kształtowanie relacji międzynarodowych. Do najważniejszych wartości można zaliczyć trwały pokój, wolność, demokrację, prawa człowieka, rządy prawa, równość, solidarność społeczną, zrównoważony rozwój i dobre zarządzanie. Działania podejmowane przez UE w celu promocji wartości są różnorakie i obejmują rozwój handlu i współpracy regionalnej, udzielanie pomocy rozwojowej, nawiązywanie dialogu politycznego, prowadzenie polityki rozszerzania lub też wspieranie integracji w innych częściach świata. Ocena wpływu promocji wartości obejmuje socjalizację, partnerstwo i „posiadanie". Socjalizacja to bycie częścią procesu zaangażowania, debaty i zrozumienia. Partnerstwo obejmuje instytucjonalizację stosunków pomiędzy uczestniczącymi stronami o charakterze wielostronnym, międzynarodowym lub transnarodowym. Natomiast „posiadanie” obejmuje praktyki wspólnego lub lokalnego „posiadania” będącego rezultatem zaangażowania partnera lokalnego i konsultacji z nim ${ }^{36}$. Normatywny charakter działań ma wpływ nie tylko na partnerów, którzy są nimi objęci, ale również na Unię Europejską, która może się zmieniać jako aktor na arenie międzynarodowej.

\section{STRATEGIA PROMOCJI DEMOKRACJI UNII EUROPEJSKIEJ JAKO POTĘGI NORMATYWNEJ}

Promocja demokracji jest jednym z najważniejszych elementów strategii Unii Europejskiej jako potęgi normatywnej. Nie ulega wątpliwości, że od momentu przyjęcia Traktatu o Unii Europejskiej z Maastricht ${ }^{37}$ na początku lat 90 . XX w., co zbiegło się w czasie z rozpoczęciem procesu transformacji systemowej w państwach Europy Środkowej i Wschodniej, jednym z zasadniczych celów powstałej wówczas Wspólnej Polityki Zagranicznej i Bezpieczeństwa jest rozwój i konsolidacja demokracji i rządów prawa oraz troska o poszanowanie praw człowieka i podstawowych wolności. Zgodnie z raktatem nicejskim ${ }^{38}$ cele te mają być także osiągane $\mathrm{w}$ odniesieniu do współpracy gospodarczej, finansowej i technicznej z państwami trzecimi. Sformułowania te zostały jeszcze bardziej wzmocnione przez traktat lizboński ${ }^{39}$, który stanowi w sposób następujący: Dziatania Unii na arenie międzynarodowej oparte sa na zasadach, które leża u podstaw jej utworzenia, rozwoju i rozszerzenia oraz które zamierza wspierać na świecie: demokracji, państwa prawnego, powszechności i niepodzielności praw cztowieka i podstawowych wolności, poszanowania godności ludzkiej, zasad równości i solidarności oraz poszanowania zasad Karty Narodów Zjednoczonych oraz prawa międzynarodowego (art. 21 Traktatu o Unii Europejskiej). Stwierdzenie to jest wyraźnym odbiciem koncepcji Unii

36 Przez „posiadanie” (ownership) należy rozumieć współdecydowanie lub decydowanie przez lokalnego partnera lub też traktowanie jakiegoś programu lub działania jako własnego.

37 Traktat o UE z Maastricht został wynegocjowany na Konferencji Międzyrządowej, która trwała od grudnia 1990 r. do grudnia 1991 r. Po okresie ratyfikacji wszedł w życie 1 XI 1993 r.

38 Traktat nicejski wszedł w życie 1 II 2003 r.

39 Traktat lizboński wszedł w życie 1 XII 2009 r. 
Europejskiej jako potęgi normatywnej, która promuje na arenie międzynarodowej wartości leżące u podstaw jej funkcjonowania.

Normy traktatowe zostały potwierdzone w innych dokumentach Unii Europejskiej. We wnioskach Rady z 25 czerwca 2001 r. i 11 marca 2002 r. podkreślono zaangażowanie Unii na rzecz takich zasad, jak wolność, demokracja, poszanowanie praw człowieka, praw podstawowych i rządów prawa, które mają kierować polityką UE w zakresie praw człowieka i demokratyzacji ${ }^{40}$. Strategia promocji demokracji została rozwinięta w pierwszej Europejskiej Strategii Bezpieczeństwa, przygotowanej przez Javiera Solanę, wówczas wysokiego przedstawiciela do spraw Wspólnej Polityki Zagranicznej i Bezpieczeństwa, i przyjętej przez Radę Europejską 12 grudnia 2003 r. Dokument ten powstał jako reakcja na unilateralizm Stanów Zjednoczonych. W zakresie promocji demokracji różnił się od doktryny prezydenta USA George’a W. Busha (2001-2009), który nie wykluczał użycia siły w celu eksportu norm demokratycznych ${ }^{41}$. W taki sposób m.in. administracja amerykańska uzasadniała interwencję w Iraku w 2003 r., stąd jej nazwa Operacja Iracka Wolność.

Unia Europejska jako potęga normatywna wyklucza możliwość użycia siły w celu demokratyzacji i wiąże swoją strategię z efektywnym multilateralizmem. Postulując ustanowienie porządku międzynarodowego opartego na efektywnych stosunkach wielostronnych, Unia dąży do rozwoju silniejszej społeczności międzynarodowej, dobrze funkcjonujących instytucji międzynarodowych i opartego na prawie porządku międzynarodowego ${ }^{42}$. W tym kontekście podkreśla się w Europejskiej Strategii Bezpieczeństwa potrzebę demokratyzacji: Jakość spoteczności międzynarodowej jest uzależniona od jakości rząów, będących jej podstawą. Najlepsza gwarancja naszego bezpieczeństwa jest świat ztożony z dobrze rządzonych panstw demokratycznych. Rozpowszechnianie dobrych rząów, popieranie reform spotecznych i politycznych, walka z korupcja i nadużywaniem wtadzy, ustanawianie państwa prawa i ochrona praw cztowieka sa najlepszymi sposobami umacniania porzadku międzynarodowego ${ }^{43}$.

W sposób wyraźny promocja demokracji jest traktowana jako element przyczyniający się do stworzenia globalnego systemu demokratycznego zarządzania, gdyż jak podkreślił w 2009 r. ówczesny przewodniczący Komisji Europejskiej Jose Manuel Barroso, Unia Europejska ma multilateralizm w swoim DNA i dąży do tego, aby stabil-

40 Droits de l'homme et démocratisation dans les pays tiers - conclusions, Conseil, Bruxelles 25 VI 2001, [online] file:///C:/Users/A/Downloads/PRES-01-250_FR\%20(1).pdf, 11 VIII 2015; 2416th Cuncil Meeting, General Affairs, UN-Commission in Geneva - Council conclusions, Brussels, 11 III 2002, 6596/02 (Presse 48), [online] http://www.consilium.europa.eu/ueDocs/cms_Data/docs/pressData/ en/gena/69769.pdf, 11 VIII 2015.

${ }^{41}$ Na temat różnic pomiędzy strategiami promocji demokracji UE i USA zob.: A. Podraza, Towards a New System of Global Democratic Governance: the Transatlantic Security Community and the Role in Democracy Promotion in the 21st Century, [w:] Global Challenges to the Transatlantic World, red. C. Crespo i in., Alcala de Henares-Madrid 2015, s. 73-84, Biblioteca Benjamin Franklin. Política.

42 Rada Europejska, Europejska Strategia Bezpieczeństwa „Bezpieczna Europa w lepszym świecie”, Bruksela, 12 XII 2003, s. 9.

43 Tamże, s. 10. 
ność, wolność, demokracja i sprawiedliwość dominowały jako fundamenty stosunków międzynarodowych ${ }^{44}$.

Z tego też powodu w Europejskiej Strategii Bezpieczeństwa podkreśla się znaczenie wzmocnienia Organizacji Narodów Zjednoczonych, co jest zgodne z unijnym mitem założycielskim ponadnarodowego zarządzania jako antidotum na anarchię międzynarodową ${ }^{45}$. Promocja demokracji ${ }^{46}$, także w odniesieniu do państw Europy Wschodniej, jest wobec tego w dużej mierze traktowana jako element globalnej strategii stworzenia nowego porządku międzynarodowego, który bazowałby na liberalnym paradygmacie współpracy i współzależności przeciwstawnym realistycznemu podejściu opartemu na sile i interesach. To drugie stanowisko charakteryzuje przede wszystkim politykę Stanów Zjednoczonych, dla których promocja demokracji staje się ważniejsza jako cel polityki zagranicznej, jeżeli lepiej służy to interesom narodowym.

Różnice pomiędzy europejskim i amerykańskim podejściem do promocji demokracji nie dotyczą tylko politycznego i teoretycznego uzasadnienia tej strategii, ale związane są także z określeniem przedmiotu wsparcia. Strategia Stanów Zjednoczonych ma charakter z dołu do góry (bottom-up), czyli koncentruje się przede wszystkim na wspomaganiu rozwoju społeczeństwa obywatelskiego ${ }^{47}$. Strategia Unii Europejskiej ma charakter z góry do dołu (top-down) poprzez uznanie roli państwa i koncentrowanie się na wymiarze instytucjonalnym procesu demokratyzacji.

Te dwa idealne modele promocji demokracji są traktowane jako tradycyjne i bazują na podstawowych teoriach demokratyzacji rozwijanych w latach 60 . i $80 . \mathrm{XX} \mathrm{w}^{48}$ Pierwszy można określić mianem modelu sprzężenia (linkage), gdyż endogenna demokratyzacja jest zależna od rozwoju społeczno-gospodarczego. Drugi można nazwać modelem wpływu (leverage), gdyż w procesie transformacji demokratycznej ukazuje się rolę elit w tym zakresie.

Freyburg, Lavenex, Schimmelfenning, Skripka i Wetzel proponują również uwzględnić trzecie podejście do demokratyzacji, określone jako model zarządzania (governance) zewnętrzną promocją demokracji. Występuje ono w ramach funkcjonalnej sektorowej współpracy pomiędzy aktorami administracyjnymi. W ramach poszczegól-

44 J.M. Barroso, Europe’s Rising Global Role, Project Syndicate, 16 XII 2009, [online] https://www.project-syndicate.org/commentary/europe-s-rising-global-role, 18 XII 2009.

45 A. Toje, The European Union as a Small Power. After the Post-Cold War, Basingstoke 2011, s. 91.

46 Szczegółowym problemem promocji demokracji w wydaniu Unii Europejskiej jest kwestia, jaka forma demokracji jest eksportowana do państw trzecich. Podejście UE w tym zakresie jest charakteryzowane jako „rozmyty liberalizm”, gdyż Unia na przemian eksportuje modele demokracji liberalnej bądź demokracji społecznej. R. Hanau Santini, O. Hassan, Transatlantic Democracy Promotion and the Arab Spring, „The International Spectator: Italian Journal of International Affairs” 2012, Vol. 47, nr 3, s. 71, [online] http://dx.doi.org/10.1080/03932729.2012.700021.

47 J. Kopstein, The Transatlantic Divide over Democracy Promotion, „The Washington Quarterly” 2006, Vol. 29, nr 2, s. 93-97, [online] http://dx.doi.org/10.1162/wash.2006.29.2.85.

48 T. Freyburg i in., Democracy Promotion by Functional Neighbourhood. The European Union and its Neighbourhood, Basingstoke 2015, s. 1-8, Challenges to Democracy in the 21st Century; ciż, Democracy Promotion Through Functional Cooperation? The Case of the European Neighbourhood Policy, „Democratization" 2011, Vol. 18, nr 4, [online] http://dx.doi.org/10.1080/13510347.2011.584738. 
nych sektorów polityki publicznej przygotowuje się prawno-administracyjne podstawy zarządzania demokratycznego poprzez transfer zasad proceduralnych, takich jak transparentność i odpowiedzialność za działalność publiczną oraz społeczny udział w procesach decyzyjnych. Taka forma demokratyzacji realizowana jest przede wszystkim $\mathrm{w}$ momencie dostosowywania krajowego prawodawstwa do acquis communautaire, czyli dorobku prawnego Unii Europejskiej, i może się odbywać niezależnie od reformowania struktur państwa. Może ona też mieć miejsce na szczeblu lokalnym w momencie realizacji konkretnych projektów rozwojowych, w których finansowo partycypują podmioty lokalne, ale zakłada się również aktywny udział i współpracę lokalnych władz, przedsiębiorców i wspólnoty ${ }^{49}$.

Należy jednak zadać pytanie o skuteczność takiej formy promocji demokracji, gdyż jej możliwości wydają się mocno ograniczone. Wpływanie na kształtowanie kultury prawnej i administracyjnej państwa demokratycznego w procesie zbliżania się do norm prawa europejskiego może mieć znaczenie tylko wtedy, gdy celem działań dostosowawczych jest pełne członkostwo w Unii Europejskiej. Co więcej, o czym świadczą przykłady państw Europy Wschodniej, takich jak Mołdawia czy Ukraina, sam proces przyjmowania i wdrażania norm prawa europejskiego nie ma zasadniczego wpływu na kształtowanie się systemu politycznego, którego rozwój jest przede wszystkim zależny od panującej kultury politycznej. Innymi słowy, Unia Europejska poprzez wykorzystywanie narzędzia prawnej harmonizacji nie jest w stanie zmierzyć się z podstawowymi problemami demokracji ukraińskiej dotyczącymi oligarchizacji polityki i gospodarki, spuścizny komunizmu przy jednoczesnych słabościach w rozwoju społeczeństwa obywatelskiego czy też ukształtowania narodowej tożsamości ukraińskiej w skali całego państwa. Konstatacja taka jest świadectwem ograniczonego wpływu Unii na państwa objęte różnymi formami współpracy i pomocy w ramach polityki sąsiedztwa.

\section{KONKLUZJE I REKOMENDACJE}

Biorąc pod uwagę powyższe rozważania, można dojść do wniosku, że jakkolwiek Unia Europejska jest aktywnym i ważnym podmiotem we wspomaganiu procesu demokratyzacji w państwach Europy Wschodniej, w tym przede wszystkim na Ukrainie, to jednak jej strategia w zakresie promocji demokracji i polityka wschodnia cierpi na szereg ograniczeń. Wynikają one z uwarunkowań wewnętrznych związanych z niezakończonym procesem kształtowania się podmiotowości prawnomiędzynarodowej Unii oraz problemów w kształtowaniu wyrazistej i spójnej Wspólnej Polityki Zagranicznej i Bezpieczeństwa w reakcji na aktywność innych podmiotów, w tym przede wszystkim Rosji. Zwiększenie możliwości oddziaływania przez Unię Europejską na inne podmioty zależne jest wobec tego od istotnej transformacji UE jako uczestnika stosunków międzynarodowych.

Po pierwsze, państwa członkowskie muszą doprowadzić do rzeczywistego, a nie tylko formalnego upodmiotowienia Unii Europejskiej na arenie międzynarodowej. Nale-

49 N. Shapovalova, Assessing Democracy Assistance: Ukraine, FRIDE, V 2010, s. 9. 
ży ostatecznie rozwiązać problem międzynarodowego aktorstwa UE. Jest on identyfikowany od lat, ale pomimo istotnych reform traktatowych, począwszy od Jednolitego aktu europejskiego aż do traktatu lizbońskiego, międzynarodowe znaczenie Unii jest ograniczone, gdyż organizacja ta jest bardziej instrumentem w rękach państw członkowskich niż kolektywnym graczem. To, czego brakuje, to przede wszystkim wola polityczna państw członkowskich, a nie możliwości prawno-traktatowych. Nie jest to więc problem o charakterze strukturalnym ${ }^{50}$, ale wyraźnie politycznym. Należy dążyć do tego, aby Unia mówiła jednym głosem na arenie międzynarodowej poprzez wypracowywanie spójnych i ambitnych stanowisk. Unijne posady, w tym wysokiego przedstawiciela do spraw zagranicznych i polityki bezpieczeństwa, powinny być zajmowane przez wyraziste osobowości posiadające wcześniejszą istotną praktykę w realizacji polityki zagranicznej. Dotychczasowe doświadczenia w tym zakresie są rozczarowujące, gdyż można dojść do przekonania, że największe państwa członkowskie doprowadzają do mianowania odpowiedzialnymi za WPZiB takich osób, które można lepiej kontrolować. WPZiB nie powinna być narzędziem w rękach największych państw, które poprzez procedury unijne chcą realizować własne partykularne interesy narodowe.

Po drugie, Unia Europejska powinna przyjąć bardziej realistyczną, a nie tylko podyktowaną polityczną kalkulacją strategię wobec Moskwy, uwzględniając rozwój sytuacji wewnętrznej w Rosji i realizowaną przez to państwo politykę zagraniczną. Strategia nie powinna odzwierciedlać jedynie wąskich interesów gospodarczych o krótkoterminowym charakterze niektórych państw członkowskich, ale uwzględnić reperkusje polityczne w dalszej perspektywie czasowej. Neoimperialna polityka realizowana przez Putina jest w dużej mierze wynikiem słabości Zachodu, w tym także Unii Europejskiej. Jednoznaczne określenie zasad relacji z Rosją pomoże Unii Europejskiej w kształtowaniu stosunków z innymi państwami powstałymi po rozpadzie Związku Radzieckiego. Swoisty strach przed Rosją ogranicza możliwości rozwoju polityki wschodniej UE.

Po trzecie, głównym celem w polityce wschodniej Unii Europejskiej powinno być jasne określnie ostatecznego celu dla państw stowarzyszonych w postaci pełnego członkostwa, ale po rygorystycznym spełnieniu kryteriów akcesyjnych. Strategia otwarcia powinna bazować na polityce warunkowości i dyferencjacji przy wyraźnie zdefiniowanych warunkach stopniowego zbliżania do systemu. Tylko w takiej sytuacji polityka promocji demokracji będzie mogła przynieść efekty, tzn. przyczynić się do rozwoju demokracji w państwach Europy Wschodniej i wzmocnienia bezpieczeństwa europejskiego.

Po czwarte, testem dla skuteczności polityki wschodniej Unii Europejskiej jest stosunek do Ukrainy, zarówno jeżeli chodzi o pomoc w rozwiązaniu kryzysu ukraińskiego (szerszy wymiar międzynarodowy), jak i wykorzystanie wszystkich możliwości wynikających z umowy stowarzyszeniowej z Ukrainą. W znalezieniu rozwiązania politycznego kryzysu ukraińskiego powinna uczestniczyć Unia Europejska jako całość działa-

50 W sensie strukturalnym można doprowadzić do ujednolicenia stanowiska UE poprzez wyraźną dominację jednego lub kilku państw w procesie decyzyjnym lub też federalizację WPZiB. Biorąc pod uwagę fakt, że w odniesieniu do polityki zagranicznej w grę wchodzą często jasno zdefiniowane i sprzeczne interesy narodowe państw członkowskich, tego rodzaju możliwości są raczej trudne do zrealizowania. 
jąca w interesie wszystkich państw członkowskich. Obecny model negocjacji w postaci formatu normandzkiego jest wyraźnym sygnałem renacjonalizacji w zakresie WPZiB. Natomiast strategia pełnej integracji Ukrainy z Unią Europejską powinna bazować na umowie stowarzyszeniowej. Bez określenia członkostwa jako ostatecznego celu w rozwoju stosunków z takimi państwami, jak Ukraina i Mołdawia, Unia Europejska nie będzie w stanie wywrzeć istotnego wpływu na stabilizowanie środowiska międzynarodowego i stworzenie systemu bezpieczeństwa europejskiego. Ewentualny sukces Ukrainy może stanowić przykład dla Rosji, zarówno dla społeczeństwa, jak i elit politycznych. Trudno jednak przypuszczać, aby w perspektywie kilku lub nawet kilkunastu lat Rosja porzuciła konfrontacyjną politykę zagraniczną na rzecz współpracy z państwami i instytucjami europejskimi oraz transatlantyckimi przy pełnym poszanowaniu suwerenności państw powstałych w wyniku rozpadu Związku Radzieckiego. Taka postawa Rosji będzie oczywiście testem dla Unii Europejskiej i jej aktywności jako aktora na arenie międzynarodowej.

\section{BIBLIOGRAFIA}

Barany Z., NATO's Peaceful Advance, "Journal of Democracy” 2004, Vol. 15, nr 1, [online] http://dx.doi.org/10.1353/jod.2004.0002.

Barroso J.M., Europe's Rising Global Role, Project Syndicate, 16 XII 2009, [online] https:// www.project-syndicate.org/commentary/europe-s-rising-global-role.

Bugajski J., Russia's Transformation, „The Journal of International Security Affairs” 2014, nr 27, [online] http://www.securityaffairs.org/issues/number-27/russias-transformation.

Dragneva R., Wolczuk K., Russia, the Eurasian Customs Union and the EU: Cooperation, Stagnation or Rivalry?, 2012, Chatham House Briefing Paper, REP BP 2012/01.

Droits de l'homme et démocratisation dans les pays tiers - conclusions, Conseil, Bruxelles, $25 \mathrm{VI}$ 2001, [online] file:///C:/Users/A/Downloads/PRES-01-250_FR\%20(1).pdf..

Emerson M., Kostanyan H., Putin's Grand Design to Destroy the EU's Eastern Partnership and Replace It with a Disastrous Neighbourhood Policy of His Own, Brussels 2013, CEPS Commentary.

Forbrig J., Introduction: A Region Disunited?, [w:] A Region Disunited? Central European Responses to the Russia-Ukraine Crisis, red. tenże, Washington 2015, Europe Policy Paper, $1 / 2015$.

Freyburg T. i in., Democracy Promotion by Functional Neighbourhood. The European Union and its Neighbourhood, Basingstoke 2015, Challenges to Democracy in the 21st Century.

Freyburg T. i in., Democracy Promotion Through Functional Cooperation? The Case of the European Neighbourhood Policy, „Democratization” 2011, Vol. 18, nr 4, [online] http://dx.doi. org/10.1080/13510347.2011.584738.

Gerrits A., Normative Power Europe: Introductory Observations on a Controversial Notion, [w:] Normative Power Europe in a Changing World. A Discussion, red. tenże, The Hague 2009, Clingendael European Paper. 
Hanau Santini R., Hassan O., Transatlantic Democracy Promotion and the Arab Spring, ,The International Spectator: Italian Journal of International Affairs” 2012, Vol. 47, nr 3, [online] http://dx.doi.org/10.1080/03932729.2012.700021.

Herpen M.H. van, Putin's Wars. The Rise of Russia's New Imperialism, Lanham 2014.

Hyde-Price A., „Normative” Power Europe: A Realist Critique, „Journal of European Public Policy” 2006, Vol. 13, nr 2, [online] http://dx.doi.org/10.1080/13501760500451634.

Jarosiewicz A., Fischer E., Eurazjatycka Unia Gospodarcza - więcej polityki, mniej gospodarki, Warszawa 2015, Komentarze OSW, nr 157, [online], http://www.osw.waw.pl/pl/pub likacje/komentarze-osw/2015-01-20/eurazjatycka-unia-gospodarcza-wiecej-politykimniej-gospodarki.

Juncos A.E., The EU's Post-Conflict Intervention in Bosnia and Herzegovina: (Re)Integrating the Balkans and/or (Re)Inventing the EU?, „Southeast European Politics” 2005, Vol. 6, nr 2.

Kopstein J., The Transatlantic Divide over Democracy Promotion, „The Washington Quarterly” 2006, Vol. 29, nr 2, [online] http://dx.doi.org/10.1162/wash.2006.29.2.85.

Kupchan Ch.A., NATO's Final Frontier: Why Russia Should Join the Atlantic Alliance, „Foreign Affairs" 2010, Vol. 89, nr 3.

Light M., White S., Löwenhardt J., A Wider Europe: The View from Moscow and Kyiv, „International Affairs" 2000, Vol. 76, nr 1, [online] http://dx.doi.org/10.1111/1468-2346.00121.

Manners I., The European Union's Normative Power in Global Politics, [w:] Key Controversies in European Integration, red. H. Zimmermann, A. Dür, Basingstoke 2012, European Union Series.

Manners I., The Normative Ethics of the European Union, „International Affairs” 2008, Vol. 84, nr 1, [online] http://dx.doi.org/10.1111/j.1468-2346.2008.00688.x.

Maull H.W., Germany and Japan: The New Civilian Powers, „Foreign Affairs” 1990, Vol. 69, nr 5.

Orbie J., Civilian Power Europe. Review of the Original and Current Debates, „Cooperation and Conflict" 2006, Vol. 41, nr 1, [online] http://dx.doi.org/10.1177/0010836706063503.

Peterson J., Gottwald M., The EU as a Global Actor, [w:] The European Union. How Does It Work?, red. D. Kenealy, J. Peterson, R. Corbett, Oxford 2015, The New European Union Series.

Pitty R., Disintegrating European Austerity in Greece and Germany, [w:] Democracy and Crisis. Democratising Governance in the Twenty-First Century, red. B. Isakhan, S. Slaughter, Basingstoke 2014.

Podraza A., Stosunki polityczne i gospodarcze Wspólnoty Europejskiej z państwami Europy Środkowej $i$ Wschodniej, Lublin 1996.

Podraza A., Towards a New System of Global Democratic Governance: the Transatlantic Security Community and the Role in Democracy Promotion in the 21st Century, [w:] Global Challenges to the Transatlantic World, red. C. Crespo i in., Alcala de Henares-Madrid 2015, Biblioteca Benjamin Franklin. Politica.

Podraza A., Unia Europejska w procesie reform traktatowych, Lublin 2007.

Putin Deplores Collapse of USSR, BBC News, 25 IV 2005, [online] http://news.bbc.co.uk/2/ hi/4480745.stm. 
Putin Names Nato among Threats in New Russian Security Strategy, „Financial Times” 2016, 2 I, [online] http://www.ft.com/intl/cms/s/0/6e8e787e-b15f-11e5-b147-e5e5bba42e51. html\#axzz42cyIVx9l.

Rada Europejska, Europejska Strategia Bezpieczeństwa „Bezpieczna Europa w lepszym świecie”, Bruksela, 12 XII 2003.

Romanova T., Normative Power Europe: A Russian View, [w:] Normative Power Europe in a Changing World. A Discussion, red. A. Gerrits, The Hague 2009, Clingendael European Paper. Russia's Foreign Policy. Ideas, Domestic Politics and External Relations, red. D. Cadier, M. Light, Basingstoke 2015, Palgrave Studies in International Relations.

Sakwa R., The Death of Europe? Continental Fates after Ukraine, „International Affairs” 2015,

Vol. 91, nr 3, [online] http://dx.doi.org/10.1111/1468-2346.12281.

Shapovalova N., Assessing Democracy Assistance: Ukraine, FRIDE, V 2010.

Sjursen H., What Kind of Power?, [w:] Civilian or Military Power? European Foreign Policy in Perspective, red. taż, London-New York 2007, Journal of European Social Policy.

Toje A., The European Union as a Small Power. After the Post-Cold War, Basingstoke 2011.

2416th Cuncil Meeting, General Affairs, UN-Commission in Geneva - Council conclusions, Brussels, 11 III 2002, 6596/02 (Presse 48), [online] http://www.consilium.europa.eu/ueDocs/ cms_Data/docs/pressData/en/gena/69769.pdf.

Walker Ch., The New Containment. Undermining Democracy, „World Affairs” 2015, Vol. 178, nr 1 .

Dr hab. Andrzej PODRAZA, prof. KUL - kierownik Katedry Stosunków Międzynarodowych w Instytucie Nauk Politycznych i Spraw Międzynarodowych KUL. 